\title{
Biodiversity and the Basic Aspects of Its Preservation
}

\author{
Mirjana Milošević · Aleksandar Mikić · Ana Marjanović Jeromela
}

\begin{abstract}
Summary: Biodiversity, or diversity of plant resources in agriculture, is a biological basis of global food providing, directly or indirectly. Biodiversity implies diversity of genetic material contained in traditional and contemporary newly created genotypes. Mentioned resources could be the basis for the creation of new cultivars through conventional crossbreeding process or application of biotechnology. Plant resources include both wild relatives and other wild plant species that could be used as an energy source, for pharmaceutical purposes and as a source of beneficial genes. Genetic material is a reservoir of genetic adaptability that can prove to be a buffer against potentially harmful external or economic changes, regardless of the purpose and technology used. Erosion of plant resources could have serious and longterm effect on food supply.

Keywords: biodiversity, climate change, diversity, economic development, ecosystems, genetics, plant resources, preservation
\end{abstract}

\section{Introduction}

Plants and organisms that photosynthesize are systems that provide life on Earth. They are ingredients of feed and structural substances of other organisms' great number of cells. Unique process of photosynthesis results in creation of biomass needed for all living organisms. That means that plants are the heart of our food chain. It took millennia for humankind to go through the process of population selection to create plants that are more appropriate for their needs. Such plants represent real treasury of genes to be retained.

Biodiversity, or diversity of plant resources in agriculture, is biological basis of global food providing, directly or indirectly. Biodiversity implies diversity of genetic material contained in traditional and contemporary newly created genotypes. Mentioned resources could be the basis for the creation of new varieties through conventional crossbreeding process or application of biotechnology. Plant resources include both wild relatives and other wild plant species that could be used as an energy source for pharmaceutical purposes; as a source of beneficial genes. Genetic material is a reservoir of genetic adaptability that can prove to be a buffer against potentially harmful external or economic

M. Milošević

Retired professor, University of Novi Sad, Faculty of Agriculture, Trg D. Obradovića 8, 21000 Novi Sad, Serbia

A. Mikić* · A. Marjanović Jeromela

Institute of Field and Vegetable Crops, Maksima Gorkog 30, Novi Sad, Serbia

e-mail: aleksandar.mikic@nsseme.com changes, regardless of the purpose and technology used. Erosion of plant resources could have serious and long-term effect on safety of food supply (Milošević at al. 2009).

\section{The Concept and Importance of Biodiversity}

\section{The Concept of Biodiversity}

Biodiversity (biological diversity) is a complex term that covers many aspects of biological variation. It is the most commonly used word to describe all types of organisms that live in a particular area. Viewed from our planet's level, it could be defined as "life on Earth". Researchers involved in studying biodiversity use broader definitions, so that biodiversity includes not only living organisms and their interactions with each other, but also their interaction with abiotic factors of the environment they live in. Therefore, biodiversity may be defined as the diversity of life on Earth at all its levels, from genes to ecosystems, and as ecological and evolutionary processes that create it (NBSAP 2013).

Influence of external effects (climatic, edaphic and topographic), affecting by selection pressure on traits of plants that are observed, is illustrated by an expert of Nordic Gene Bank, Endersen (2009) in Figure 1. The specified data are important for collecting plants through passport data in gene banks. The manner in which results are shown is accessible to researchers who can evaluate the effect of environmental factors on biodiversity and identify the approach to the process of genetic variation for individual traits of plants (Endersen 2009). 


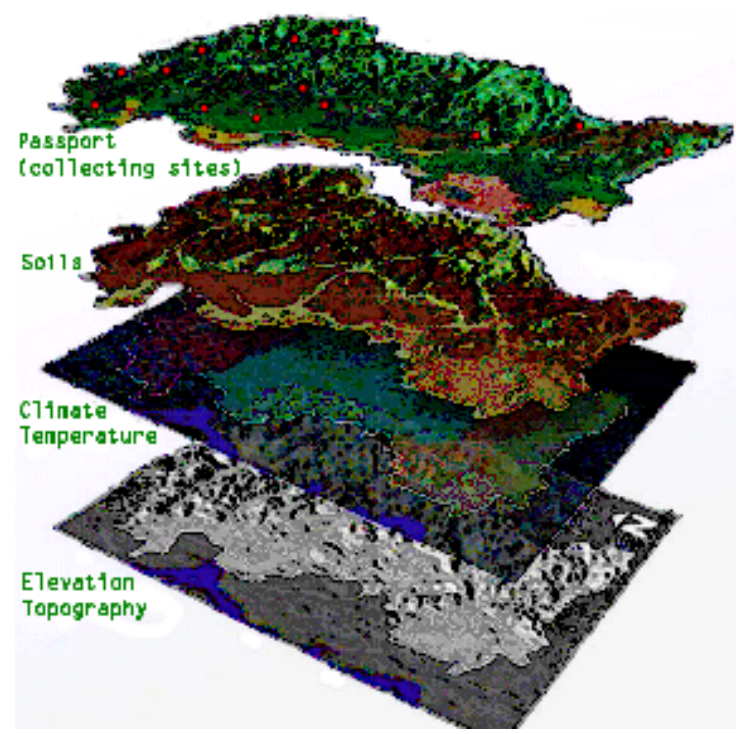

Figure 1. Factors affecting the preservation of biodiversity (Endersen, D.T.F.)

\section{Importance of Biodiversity}

When it comes to biodiversity, diversity is of immense value for the humankind. Due to it, all species, including human, have survived despite the changes that have emerged during the development of civilization, contrary to often destructive attitude of humans toward nature. Biodiversity is an evolutionary response to the constant variability of environmental conditions. Biodiversity is responsible for process of creating organic matter where oxygen releases and fixes carbon dioxide, which affects balance of the basic elements that constitute air. Circulation of mineral matter in nature is achieved due to living organisms, and the cycle of water circulation. Organic matter produced by plant and animal species is basis of human nutrition. Due to biodiversity, evolution of all living creatures occurs and contributes to the creation of new species. Considering that living organisms are a renewable resource, biodiversity is the only replacement for a variety of non-renewable energy resources that will be exhausted in the future (Ćosović 2008a).

There were series of attempts to comprehensively examine the biodiversity of the planet as it is today. Biologists from the University of California in San Diego and the University of Bonn compiled the global map of wealth in biodiversity in 2007. Their studies included hundreds of thousands of species, from which they made the map of biodiversity on the planet (Fig. 2). Due to rapid changes in biodiversity, this map will certainly look different in the future.

Another attempt of global biodiversity viewpoint was made by McDonald (2007), by creating a map of plant varieties wealth in 1,032 geographic regions of the world, in so-called ecoregions (Fig. 3). As you can see in the figure, biodiversity varies depending on the

\section{GLOBAL BIODIVERSITY: SPECIES NUMBERS OF VASCULAR PLANTS}

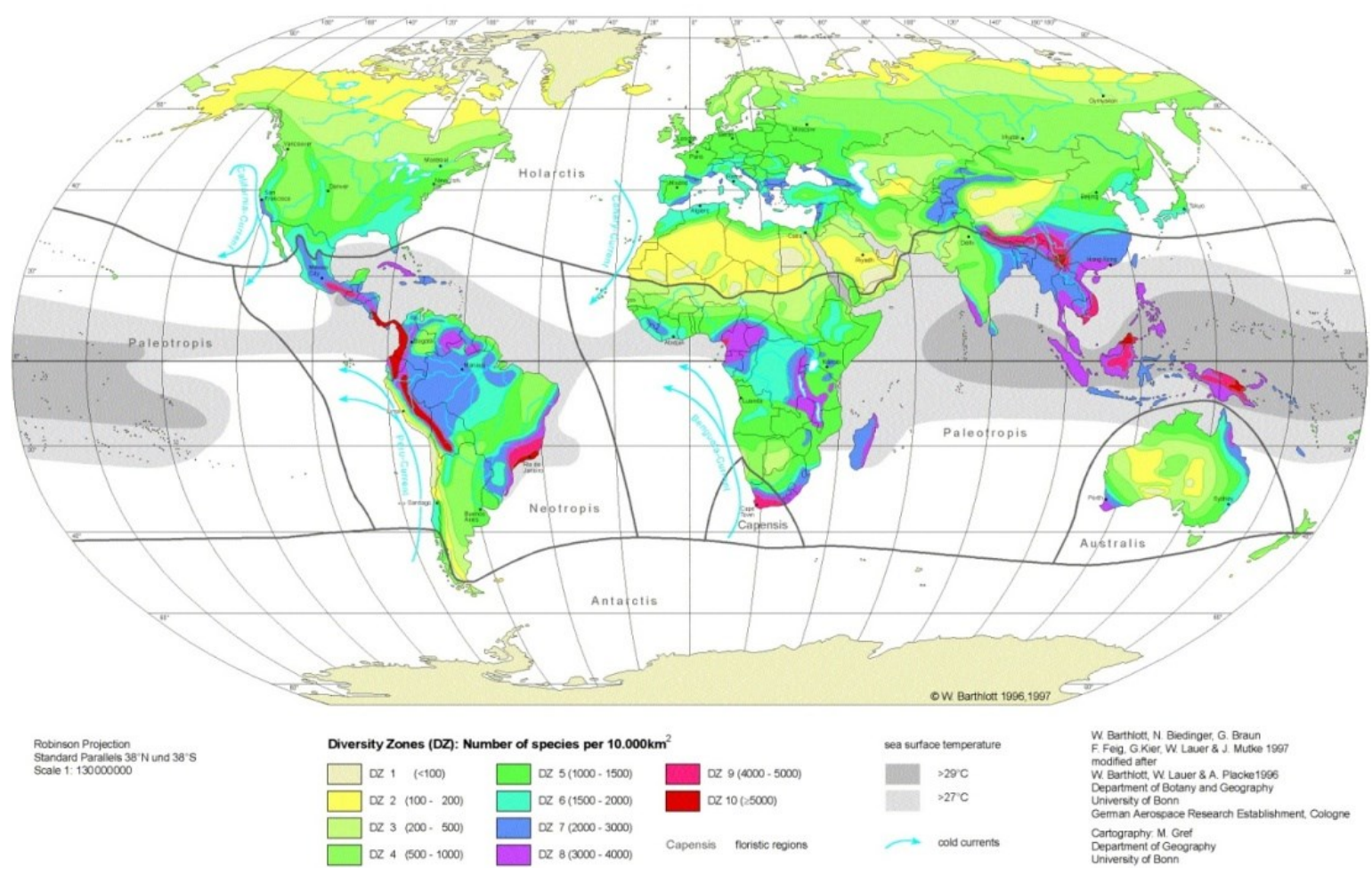

Figure 2. Global biodiversity - species numbers of vascular plants per area unit (http://www.biohere.com/images/globbiod.JPG) 
geographic region that contains plant habitats. Part $a$ represents the localities where the plant species were observed, while parts $b, c, d$, indicate the number of populations, where blue stands for the lowest population density, and red for the highest population density of plant species in the study region.

Among other things, the importance of biodiversity is in its productivity. Biodiversity and ecosystem productivity are significantly related to the types of organisms that can move through the different parts of the ecosystem (Van Vuuren et al. 2008). Researchers hope that understanding the mechanisms that determine the diversity and productivity of ecosystems would help ecologists and those who carry out conservation of genetic resources in developing a strategy that will ensure that the conserved region is highly productive and rich in biodiversity.

"Productive" ecosystems are defined as ecosystems that maintain a large amount of living matter, derived from microorganisms, plants and animals. Researchers also found that the mass measurement of the living organisms is presented by "biomass" ecosystem. Numerous studies in the previous decade showed that ecosystem with high biodiversity had richness of the species that are highly productive in a short period, but so far the process that creates a link between high levels of biodiversity and productivity over a long period has not been clarified (Milošević et al. 2010).

The differences in biomass net primary production in the ecosystem are documented in proceedings of 94th annual meeting of Environmental Society of America (ESA), depending on rainfall, solar radiation and temperature. Conclusion drawn from the submitted papers is that there is less data regarding the differences in total biomass and its consumers in relation to the ecosystem. If consumers of biomass were directly related to primary production, it could be predicted that ecosystems that are more productive support more diversity and higher biomass production for consumers (Chepko-Sade et al. 2009, Barać et al. 2011, Mihailović et al. 2010).

When the distribution of species is low, it is difficult for the populations of species that remain in parts of the ecosystems with unfavourable conditions to adapt to this environment because of the small population size and lack of genetic variability (Savić et al. 2014). When plant species are very widespread in the ecosystem, they are practically "universal" and can survive in many habitats, but cannot be successfully grown in any specific habitat. Moderate distribution of plant species creates the best conditions to ensure their survival and adaptation to ecosystems' unfavourable conditions, but not to become "universal".

Distribution of plants allows new individuals and new genes to constantly be faced with unfavourable external conditions, which is essential for evolutionary adaptation

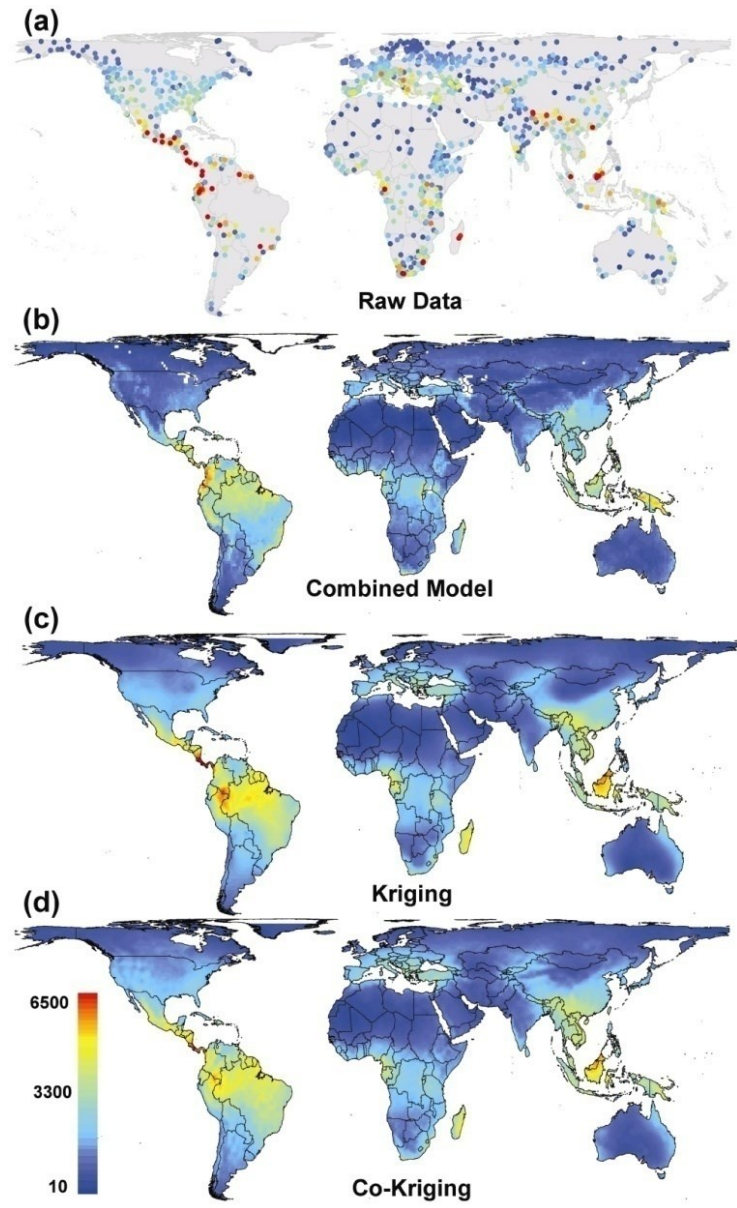

Figure 3. Wealth map of plant species in 1,032 geographic regions of the world (McDonald 2007)

to these adverse conditions. When plants are adapted to these environmental conditions, there is an increase in productivity of the ecosystem and this can increase the biodiversity, similar to distribution of plant species from different parts of the ecosystem, which creates more niches that can be exploited (MacLean 2008, Mikić et al. 2009).

\section{Biodiversity and Evolutionary Processes}

Nothing on Earth has remained as it was created, with the exception of life in all its forms. The composition, shape, colour and temperature of the Earth have changed. The composition of the atmosphere has completely changed. The continents separated and came together, creased and broke (Ćosović 2008b). A process of division and continental drift has been happening for millions of years, since Pangaea, which is an ancient homeland of all continents that formed a single continent. These changes are still happening; it is a historic, continuous, evolutionary process that inevitably leads to changes in biodiversity. 
Variations in diversity can be taken as an example of evolutionary change during millions of years of the Phanerozoic period. The trend of changes in biodiversity is clearly marked with the red line in Figure 4. Geological processes (tectonic disturbances, erosion), changes in sea level (sea transgression and regression) and changes in climate lead to significant long-term changes in the structural and spatial characteristics of global biodiversity. The processes of natural selection are often related to geological processes and influence to changes in local and global flora and fauna (Mihailović et al. 2009).

It is necessary to conserve biodiversity because of these changes (Lazić et al. 2009). Despite the progress made in this field, and according to van Vuuren et al. (2006), losses in biodiversity increased from 100 to 10,000 times, compared to fossil remains of the Cenozoic period (Van Vuuren et al. 2006).

\section{$V$ alue Measurement of Biodiversity}

Plant species are disappearing faster than biologists can identify and document them. Most of the countries signatory to the Convention on Biological Diversity, about 200 of them, agreed it was necessary to prevent the loss of biodiversity by 2010 (Veselinović et al. 2014). In order to achieve this, it is necessary to calculate and monitor trends related to the biodiversity. Experts from prestigious universities, such as the BirdLife International, in Cambridge, UK, Conservation International, International Union for Conservation of Nature - IUCN and the Zoology Institute from London, showed a new way of calculating the index for measuring risk trends for specific groups of organisms (Butchart et al. 2004).

Butchart et al. (2004) focused their research on the trends of changes that lead to increased risk of biodiversity by monitoring changes in individual plant species between categories that are on the Red List.

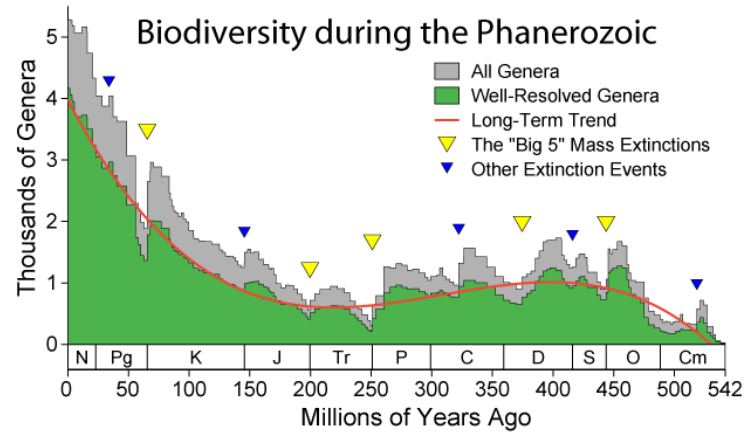

Figure 4. Changes in biodiversity during the Phanerozoic (http://en.wikipedia.org/wiki/Phanerozoic)

The list was compiled by the International Union for Conservation of Nature - IUCN. Criteria for placing some species on the Red List are population size, population trends, distribution of particular plant species, etc. The main objective of the Red List is to identify individually plant species whose survival is threatened. Another task of the Red List is to perform multi-species analysis using the data, with the task to determine and monitor the status of individual plant species (IUCN 2009, Lakušić 1999). Data were collected from researchers and it was used to calculate the degradation degree of biodiversity. The reason for this analysis was to save endangered plant species from extinction, whether by fast conservation or human actions in nature, in terms of reducing harmful effects. IUCN takes care of the plants and other living beings groups and regularly compiles a list of those that are endangered. The analysis of biodiversity noted that of all living organisms on the planet, plants were the most endangered, more than other groups of organisms, such as insects, mammals, fish, etc. It can be verified in Figure 5, which provides data from 2007, processed in 2008.

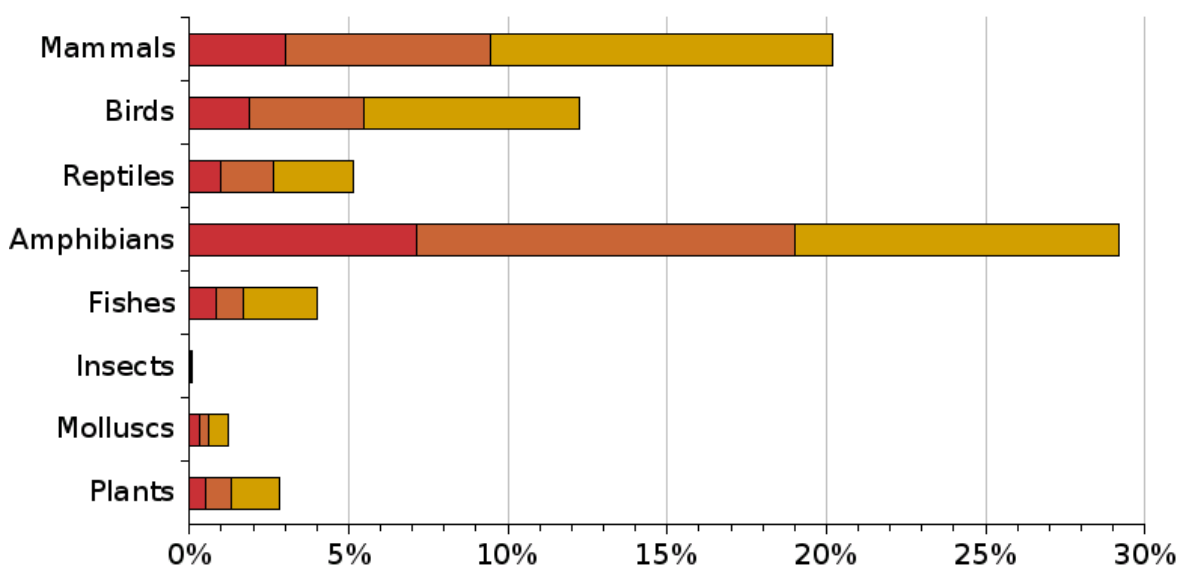

Figure 5. The percentage of species in several groups that are listed as _ critically endangered, endangered, or vulnerable

(http://en.wikipedia.org/wiki/IUCN_Red_List) 


\section{Modelling Changes in Biodiversity}

A deeper understanding of the gene fund changing process is needed in order to adopt new approaches to nature and its research methods. Research in this field has led to the development of methods of forecasting changes of biodiversity, including modelling and simulation. It will help find solutions for the sustainability of plants to unpredictable environmental changes such as global warming. Nowadays, we are working to create plants that make better use of water, nutrients, which are more resistant to extreme temperatures, $\mathrm{pH}$ value, salinity, pests and diseases, guided by the new economic needs (Mihailović 2010).

\section{A Model for Evolutionary Changes in Biodiversity}

Venail et al. (2008) suggested that evolution leads to a greater biological diversity, in particular, proving the functioning of ecosystems. In context of erosion of biodiversity, published results particularly emphasize the importance of evolution as building strength of ecosystem, which opens a new path for interpretation the relationship between the diversity of living organisms and functional ecosystem.

Experiment in laboratory conditions was carried out to prove the abovementioned. After creating a reduced model of ecosystem, several sources of carbon were used to imitate its various environments. Venail et al. (2008) observed the evolutionary diversification of Pseudomonas fluorescens bacteria. The bacteria were inoculated into each scale model of the environment (microplate with different carbon source). It could freely evolve for over 400 generations. The bacteria P. fluorescens strain SBW25 has been used in the last ten years as a model for a variety of empirical studies on evolutionary processes, conservation and use of biodiversity. This bacterium was named after its ability to produce pigment in the base that fluoresces under different conditions. Biolog GN2 microplates turn purple depending on bacterium $P$. fluorescens ability to use carbon source, while the intensity of colour depends on amount of spent carbon from different sources.

Researchers moved bacteria from one to another plate with known scattering $(0 \%, 1 \%, 10 \%$ and $100 \%)$. Scattering is known as a component, central element of evolutionary diversification. In most species, the bacterium has changed its shape and appearance into a new ecological type.

Generally, research suggests that evolution may lead to greater complexity of the ecosystem and result in its proven functioning. This process works best when available resources are different, and the biological system adequately connected. Conditions that do not meet the current trends and lead to the unification of ecosystems are the result of human activity. Viewed over a longer period, the results will be reflected in a reduced capacity of the living world and reduce diversification in the future (Venail et al. 2007, 2008).

\section{A Model for Complex Changes in Biodiversity}

Number of studies that predict future of biodiversity is small. The reason for this is the existence of a small number of models that can quantitatively measure biodiversity in relation to the changes that are anticipated. Sala et al. (2006) drafted the global assessment of different pressures on biodiversity and showed that changes in land use are major cause of loss in biodiversity, followed by climate change, reducing the concentration of nitrogen due to biotic changes and changes in the composition of atmospheric carbon dioxide. The method used was quantitative and the authors used only one scenario. It was found that the losses in the natural ecosystem would be $5-13 \%$ in the period 2000-2030 (UNEP 2002).

Millennium Ecosystem Assessment - MA has been developed to provide a complete summary of any changes in function of the ecosystem and to what it serves. A scenario that would develop changes in global and local plant diversity was used; from land use to climate change, which are the two main factors of changing biodiversity. MA included assessment of the ecosystem and its effect on human life. Qualitative and quantitative measures through the creation of models, both global and local, were used, in order to determine changes in biodiversity (Carpenter et al. 2006). Measurements were performed using the IMAGE model and Species-Area Relationship (SAR), to study possible trends in the future, in change of plant biodiversity. SAR is well set formula that establishes the number of plants per area, which reads as follows:

$$
S=c A z
$$

where $S$ is - the number of plants, $A$ is the observed area of environment, $c$ is distribution of plant species, and $z$ represents the strength of the mutual relations between the factors.

SAR was used to establish biogeographic units as large areas of relatively uniform climate, and to identify the groups of plant species and ecological communities (Kevin et al. 2004). Fourteen types of natural ecoregions of IMAGE model were found, based on soil characteristics, the primary change of climate, natural vegetation, and the carbon cycle (Fig. 6) (Olson et al. 2001).

In general, the expansion of agricultural production will continue to reduce biomass. Losses in the natural environment, as predicted by the researchers, will not evenly be distributed in the world (Hauptvogel et al. 2009).

Slightest losses will be in the Arctic in all scenarios, but in most scenarios, the biggest changes will occur in the tropics, mostly due to deforestation and conversion of land to other purposes (Sala et al. 2006). 

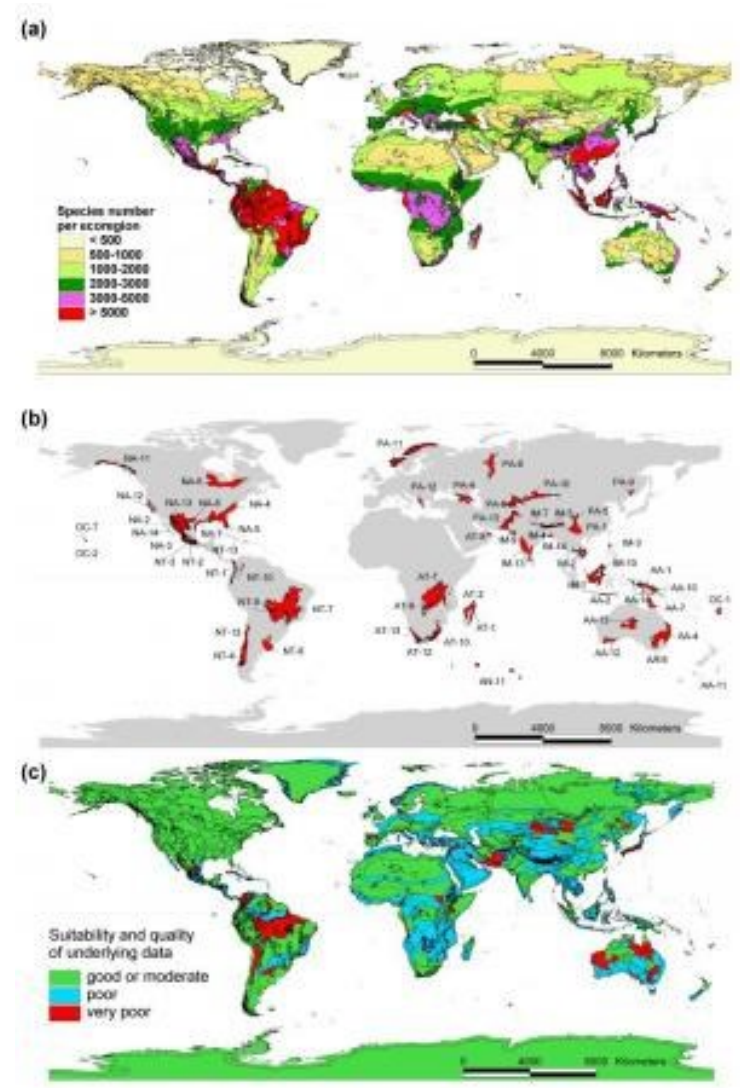

Figure 6. a) Plant species per ecoregion b) Ecoregions highest in species richness in each biome within each biogeographical realm c) Suitability and quality of underlying plant data at the scale of ecoregions (http:// www.sciencedaily.com/releases/2005/05/050512112311.htm)

Changes in local environment will be closely associated with changes in the total area of natural ecosystems. Total natural area is more or less stable in the temperature moderate zones and in the areas of same temperature. It is anticipated that the losses in the tropics will be around $15-20 \%$ in 2050 , and $30-40 \%$ in 2100 . All scenarios will come to balance in losses of biodiversity by 2050 , with a tendency to decrease by $0.1 \%$ per year. Changes may affect the ecosystem to become more sensitive to climate change (Power \& Manning 2008). Biodiversity is not just the number of plants that are located in an ecosystem, but also the plants effects on the ecosystem. Reducing number of plants with bulbs and plants with deep root systems could be taken as an example of negative change in biodiversity, caused by changes in soil structure (Dragin et al. 2009).

\section{Model for Climate Change}

Climate change will affect the ecosystem in several ways, and it is difficult to define it with a single model. The most commonly used model is one for determining effect of climate change to the distribution of biogeographic units. The real changes are much more complex, because each plant species responds individually to changes, and climate change does not always react to plants by changing biomass, and such information may not be completely accurate. Based on the available material in the IMAGE model, the effect of climate change through ratio of plant species-area is possible to determine. If it is deemed that $\mathrm{Ai}(\mathrm{t})$ is total area, of existing natural vegetation and ecoregion, and AOi $(t)$ the remaining part of original surface of covered ecoregions in 2000 , and AAi $(t)$ is a new area that covers ecoregion with now present plants and ANi $(t)$ ecoregion area where the current plant species are still not adapted, establishing the loss of biodiversity through climate change is represented with $\triangle \mathrm{ACi}(\mathrm{t})$ and losses can now be calculated in three different ways:

1.Biodiversity adapted on the basis of the adaptation speed in IMAGE: $\Delta \mathrm{AC}_{\mathrm{i}}(t)=\Delta \mathrm{AO}_{\mathrm{i}}(t)+\Delta$ $\operatorname{AA}_{\mathrm{i}}(t)+k \Delta \mathrm{AN}_{\mathrm{i}}(t)$

2.Biodiversity is not adapted, therefore causes any changes in the existing vegetation marked as loss: $\triangle \mathrm{AC}$ $(t)=\Delta \mathrm{AO}_{\mathrm{i}}(t)$

3.Biodiversity immediately adapted to climate change, and only where is potential decline of vegetation level in ecosystem, loss of biodiversity will be established: $\Delta \mathrm{AC}_{\mathrm{i}}(t)=\Delta \mathrm{AO}_{\mathrm{i}}(t)+\Delta \mathrm{AA}_{\mathrm{i}}(t)+\Delta \mathrm{AN}_{\mathrm{i}}(t)$

$K$ is a constant of calculating the loss of biodiversity on the surface that can be readily adapted. To simplify the calculation, for the value $k$ is taken the constant from the $50 \%$ loss of plant species for a particular area (Alcamo et al. 2006).

Chen et al. (2009) attempted to predict direction of further changes in biodiversity depending on time. The results of the experiment about predicting changes of British plant ecosystems influenced by global climate change were published by the end of 2008. The experiment was conducted at the Imperial College, London. The aim of the experiment was to simulate the prediction of future rainfall and their effect on the grass in the Silwood Park Campus in Berkshire. Researchers have studied how different levels of plant diversity and ecosystem respond to climate stress. The study will reflect the Intergovernmental Panel on Climate Change's (IPCC) prediction that southern England will experience up to a $30 \%$ decrease in summer rainfall and a $15 \%$ increase in winter rainfall by the year 2100 (Sala et al. 2000). The study focused on testing how important ecosystem functions, such as water, nitrogen cycling and carbon content in nature will react to significant changes of rainfall. The tests were also related to which climate changes have the greatest impact on the ecosystem and plant diversity. In further studies, different levels of biodiversity will be included because of global biodiversity decrease, associated with climate change, pollution, changing 
land use patterns and other human impacts on the environment, is predicted to increase during this century.

The research included 168 plots protected from rain, size $2.4 \times 2.4 \mathrm{~m}$ with an ecosystem consisting mainly of grasses. Rain protection covers were put away occasionally during summer, so that the researchers could control the amount of rainfall. Some of the plots were given the full amount of natural rainfall, while some plots had reduced rainfall in order to predict the impact of change on biodiversity in 2100. Rain covers were removed in winter and certain amount of water was added to the plots, again in order to simulate the natural ecosystem in 2100 (Power and Manning 2008).

Biodiversity effect on plants was measured by parameters of length and root mass, nutrients uptake, as well as other effects of photosynthesis. Based on the results, three groups of plants with similar effects were separated. In some experimental plots an increase of biodiversity was even present.

Power (2008a) from Department of Biology, Imperial College of London, UK, said: "The ecosystem will be faced with multiple challenges in years to come. Changes in rainfall will have an impact on the ecosystem properties so that will change the fundamental ecological functions such as nutrient cycle. A key challenge is to understand the effect of biodiversity loss on ecosystem functioning and its sustainability under climate change".

\section{Model That Links Nutrients to Biodiversity}

The level of nutrients in the soil can be determined by number of species found in an ecosystem, according to survey data that were published in Nature (Forde et al. 2008). For the first time mathematicians have modelled all possible differences in correlation between nutrients and biodiversity in the laboratory simulating ecosystem. They found that although nutrients definitely have an effect on biodiversity, precise ratio between two parameters depends on which plant species is present in the ecosystem. This means that in some cases low levels of nutrients can lead to a high level of biodiversity. A new study has revealed how nutrients affect the individual plant species in the ecosystem. The developed mathematical model indicated the extent to which the results can be applied in real-world environments. The study showed for the first time the actual data that confirmed the theory known as "Geographic Mosaic of Coevolution Hypothesis" may be viable in the real biodiversity (Forde et al. 2008).

\section{Economic Significance of Biodiversity}

Biodiversity is more than the diversity of plant and animal life. Biodiversity includes the total wealth of environmental and genetic information as a biological treasury in many organisms, which are yet to be explored. Experts estimate that the Earth's population is between 10 and 20 million species of animals, plants, microorganisms, that today, due to negative human effect, die a hundred to a thousand times faster. It is estimated that only in Germany one-third of species is threatened with extinction.

Today's global economy is a direct threat to the conservation of global biodiversity, because it treats the "services" of nature as something that does not cost anything, it does not take into account the damage that results with destruction or diminished effects in natural systems. Industrialization and other human activities lead to pollution of water, soil and air, reducing forest areas, which finally results is climate change and changed wildlife conditions. Result of changes is the extinction of many plant and animal species, destruction of numerous environmental systems on Earth, resulting with huge damage of world's economy and threatens the safety of all people on Earth. Price of the "services" performed by biodiversity of the Earth for humankind, the external environment and the ecosystem are difficult to assess in monetary terms. The environmental economist Costanza et al. (1997) estimated that one-year value of "service" of biodiversity for humanity is between 16-54 trillion dollars, an average of 33 trillion. Global gross domestic product - GDP (cumulative total of gross national product of all the countries) per year is 18 trillion, according to the excerpt from the material titled "The Economy of Ecosystems and Biodiversity" (TEEB, United Nations Environment Programme, 2007). German weekly magazine Spiegel estimated that the annual cost of the biodiversity loss for the world would be around $6 \%$ of global GDP by 2050 .

Constanza et al. (1997) estimated that at the current margin ecosystems provide at least US $\$ 33$ trillion dollars' worth of services annually. The majority of the value of services we could identify is currently outside the market system, in services such as gas regulation (US\$1.3 trillion per year), disturbance regulation (US\$1.8 trillion per year), waste treatment (US\$2.3 trillion per year) and nutrient cycling (US $\$ 17$ trillion per year). About $63 \%$ of the estimated value is contributed by marine systems (US $\$ 20.9$ trillion per year). Most of this comes from coastal systems (US $\$ 10.6$ trillion per year). About 38\% of the estimated value comes from terrestrial systems, mainly from forests (US\$4.7 trillion per year) and wetlands (US\$4.9 trillion per year) (Figure 7).

The global annual investment in order to prevent the extinction of species and preserve biodiversity is estimated at about 30 billion EUR (46.5 billion USD). Every dollar invested in the protection of biodiversity, according to the analysis of experts, would bring a hundred dollars profit from preserved natural systems (Töpfer 2008). 
In preparation for the G8 summit in 2007 where Germany was the host, the issue of biodiversity protection was on the list of topics, along with climate change issue, between which is a strong correlation and causality: If climate change continues at this pace, about $30 \%$ of living species on Earth will be extinct by 2050 . On the other hand, natural ecosystems, particularly forests, regulate hydrological processes and mitigate climate extremes. In preparation for this summit, Germany especially insisted on the economic aspects of preserving biodiversity.

Several specified examples may illustrate the importance and cost of certain ecosystem services:

Forests absorb carbon dioxide from the atmosphere, thereby slowing down the process of global warming of our planet, which is especially damaging to the economy (particularly agriculture); forests also regulate the supply of water (hydrological cycle, treatment) and provide pharmaceutical industry with important ingredients for medicines. The global value of pharmaceutical products derived from plants is more than 380 billion euros in industrialized countries. From $40-50 \%$ of today's medicines are derived from natural products. For oncology and anti-infective drugs, it is $70-80 \%$. With every living species that extinct, it is losing a potential treatment for some of the health problems of the world's population (Milošević et al. 2009).

It is estimated that the total value of pollination in agriculture performed by bees is $2-8$ billion annually (1.35.2 billion EUR), which is also the potential loss of bees from extinction. Therefore, mortality of bees caused by the use of some pesticides and other factors does not represent damage only for beekeepers, but for the whole community.

Germany has banned the use of eight types of insecticides, which were used to treat rapeseed and maize, since two-thirds of the bees in Baden-Wuerttemberg state died from consequences of using clothianidin (neonicotinoid pesticide). Insecticide based on imidacloprid for the treatment of sunflower was previously banned in France in 1999, when one third of the honeybees died after its use (Benjamin 2008).

German Baden-Wuerttemberg state introduced the "water penny" in addition to the price of water which subsidizes farmers who use less pesticides and fertilizers, in order to reduce water pollution and creation of greenhouse gases (from nitrogen oxides) that modify the climate (Töpfer 2008).

Reed that grows along the coast of the river Elbe in Germany, for example, performs service in the annual value of around 7.7 million euros because it purifies the polluted river water and makes construction of additional wastewater treatment facility unnecessary.

For a better understanding of the nature role and its relationship to the global economy, it should be noted that about $40 \%$ of world trade is based on biological products and processes. Biological diversity is essential for people's life, as well as for the overall economic

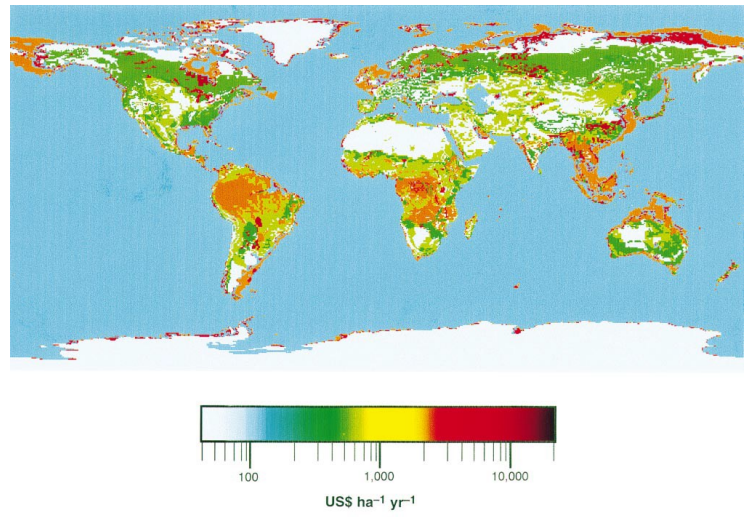

Figure 7. Global map of the value of ecosystem services

development and therefore global biodiversity policy is the core component of the global economy. Globalized and constantly growing economy uses unrecoverable natural resources rapidly (Milošević et al. 2010).

In order to protect the Earth from further destruction, the question is raised - how to make the companies, the stock market and mortgage industry accept effective criteria for investment? All of the above leads to the conclusion that it is necessary to make green globalization.

Production of natural resources in agriculture, forestry and fisheries, stable hydrological cycles, fertile soil, balanced climate and numerous other life processes occurring in the ecosystem can be permanently preserved by protection and sustainable use of biological diversity (Milošević et al. 2010).

Therefore, in addition to the key role of direct conservation, such as protected areas, ecosystems and sustainable methods of production, it is necessary to include biodiversity in all other sectors such as trade, development, finance and transport. A more radical approach to conservation of biodiversity would require application of ecological economics principles, which only now, as a discipline, enters the curriculum of some universities of the world.

\section{Sociological Importance of Biodiversity}

Biodiversity of a single country represents its richness in environmental, economic and social terms, and has great significance for the development of civilization, protection and survival of man and his environment. Biological diversity is a value that nature gives us and it should be preserved. What can a man do to save biological diversity? We need to i) preserve and improve existing biodiversity, ii) use biodiversity components and manage them in a sustainable manner, and iii) share benefits arising from the use of genetic resources in a fair way. These are general postulates about biodiversity and socio-economic point of view. Viewed from a scientific point of view, preserving biodiversity, including its classification, is quite complicated (Udruženje građana - Škola za opstanak 2004). 


\section{Conclusions: The Influence of Biodiversity on Human Health}

Human as a single genus with a single species represents a unique biological, ecological and sociological phenomenon called anthropo-diversity (Ćosović 2008b). It is certain that this unique genus depends largely on biodiversity, which determines its quality of life. The influence of biodiversity on man and his health became an international political issue. Scientific studies have shown that biodiversity loss has a negative effect on changes in population and distribution of diseases transmitters, lack of fresh water, and agricultural effects on food sources. Biodiversity changes can affect the resources available for nutrition and food security, infectious diseases, physiological and social health and spiritual health maintenance. Biodiversity plays an important role in disaster risk reduction and recovery from any disaster. Healthy ecosystem provides human population with necessary natural resources and excesses arising from the rich biological diversity regions. Numerous researchers have established the importance of biodiversity to ecosystem and human life (Reid et al. 2005, Milošević et al. 2012).

Conservation of Biodiversity Global and Ecosystem Services has confirmed the value of biodiversity and the need for its conservation. Service shows more than $70 \%$ of the world's surfaces, which have priority in the biodiversity conservation, contain significant value in supporting the ecosystem, such as fresh water and wind-protection belts, and other natural resources that allow sustainable life for man and support for social and economic development.

Climate changes, like global warming, are recognized as the biggest threat to be encountered by planet Earth. The study showing how the conservation of ecosystem provides safe preservation of biodiversity predicted a time reminder in which was stated that the investment in preservation of a healthy ecosystem and its recovery strength is important to biodiversity, to human life and economic development (Science Daily 2007).

\section{References}

Alcamo, J.A., Van Vuuren, D.P., \& Cramer, W. (2006). Changes in provisioning and regulating ecosystem goods and services and their drivers across the scenarios. Island Press, Washington, D.C., USA.

Barać, R., Duronić, G., Karagić, Đ., Vasiljević, S., \& Milošević, B. (2011). Uticaj međurednog rastojanja i setvene norme na prinos semena $\mathrm{i}$ suve materije crvene deteline (Trifolium pratense L.) Ratar. Povrt. 48(1): 155-160.

Benjamin, A. (2008). Germany bans chemicals linked to honeybee devastation. Guardian. http://www.guardian.co.uk/ environment $/ 2008 / \mathrm{may} / 23 /$ wildlife.endangeredspecies

Butchart, S.H.M., Stattersfield, A.J., Bennun, L.A., Shutes, S.M., \& Akçakaya, H.R. (2004). Measuring global trends in the status of biodiversity. PLoS Biol 2 (12): e383., Public Library Of Science, cit. Biodiversity (2009): Measuring Up To The Loss. Science Daily. http://www.sciencedaily.com- / releases/2004/10/041030153752
Carpenter, S.R., Bennett, E.M., \& Peterson, G.D. (2006). The Future of Vascular Plant Diversity Under Four Global Scenarios, in Special feature on scenarios for ecosystem services, Ecology and Society 11(2): 32. http://www.ecologyandsociety.org/vol11/iss2/ $\operatorname{art32/}$

Chen, C., Shiu, H.J., Benedick, S., Holloway, J.D., Chey, V.K., Barlow, H.S., Hill, J.K., \& Thomas, C.D. (2009). Global Impact of Climate Change On Biodiversity, Science Daily

Chepko-Sade, B.D., \& Hernandez, L. (2009). A tale of two ecosystems: Long term rodent biomass in a southern hot desert (Mapimi, Mexico) and northern temperate Forests (Oswego, New York) PS 41-189, 94th ESA annual Meeting, http://eco.confex.com/eco/2009/ techprogram/P18359.HTM

Costanza, P., Darge, R., De Groot, R., Farber, S., Grasso, M., Hannon, B., limburg, K., Naeem, Sh., Oneill, V.R., Parrelo, H., Raskin, G.R., Sutton, P., \& Van Den Belt, M. (1997). The value of the world's ecosystem services and natural capital. Nature 387: 253-260.

Ćosović, B. (2008a). Jedina konstanta prirode je život. http:// www.ekosfera.rs/vi-ministarska-konferencija/jedina-konstantaprirode-je-zivot.html

Ćosović, B. (2008b). Zaštita biodiverziteta. www.pmf.cg.ac.yu/ Download.php?file $=$ skladiste $/$ predmeti/282/.../47aa1707c5b14Zastita\%20Biodiverziteta

Diverzitet vrsta: Raznoursnost vrsta kao pokazatelj globalnog biodiveryiteta http://www.fmoit.gov.ba/bh_chm/5\%20-\%20Diverzitet $\%$ 20vrsta.pdf

Dragin S., Milošević M. Lazić B., \& Stegić M.(2009). Biodiveryitet $i$ prehrambena sigurnost. Agrarna i ruralna politika u Srbiji. Održivost agroprivrede, zadrugarstva $i$ ruralnih područja. Tematski zbornik sa međunarodnim učešćem. Društvo agrarnih ekonomista Srbije, 1 -19 , Beograd.

Endresen, D.T.F. (2009). Use case of the Crop Wild Relatives Data Portal using web services from the GBIF Data portal, Nordic Gene Bank, GBIF, Nodes Committee meeting, Amsterdam, http:// www.cropwildrelatives.org/files/cwr/2007-10-14--CWR-Global -Portal--GBIF-NODES9.pdf

Forde, S.E., Beardmore, R.E., Gudeli, I., Arkin, S.S., Thompson, J.N., \& Hurst, L.D. (2008). Understanding the limits to generalizability of experimental evolutionary models. Nature 455 (7210): 220-3, http://www.ncbi.nlm.nih.gov/ pubmed/18784724

Hauptvogel, P., Mikić, A., Hauptvogel, R., Mihailović, V., Ćupina, B., Krstić, Đ., Milošević, B., \& Jovičić, D. (2009). Fruitful results of bilateral project with Serbia. Genofond 13: 19.

http://en.wikipedia.org/wiki/IUCN_Red_List

http://en.wikipedia.org/wiki/Phanerozoic

http://www.biohere.com/images/globbiod.JPG

http://www.sciencedaily.com/releases/2005/05/050512112311.htm

http://www-biology.ucsd.edu/news/article_032007.html

IUCN, 2007

IUCN (2009): Red list, http://www.iucnredlist.org/

Lakušić, D. (ed.) (1999). Biljke koje nestaju. Ex-situ zaštita međunarodno značajnih biljaka Jugoslavije. Društvo ekologa Srbije, Zavod za zaštiti prirode Srbije, Beograd.

Lazić, B., Milošević, M., \& Dragin, S. (2009). Uloga banke biljnih gena u ónvanju $i$ korišćenju genetičkih resursa, Srpska akademija nauka i umetnosti, , Knijga 3, 305-323.

Maclean, C. (2008). The Secrets of Successful Ecosystems, Science Daily, Imperial College, London, http://www.sciencedaily.com/ releases/2008/03/080312141228.htm

McDonald, K. (2007). Biologists Produce Global Map of Plant Biodiversity, Biological sciences, http://www-biology.ucsd.edu/ news/article_032007.html

Mihailović, V., Katić, S., Mikić, A., Vasiljević, S., Karagić, Đ., \& Milošević, B. (2010). Perast - a new Serbian winter cultivar of fodder kale (Brassica oleracea L. var. viridis L.). Cruciferae Newsletter, 29: 34-35.

Mihailović, V., Mikić, A., Ćupina, B., Krstić, Đ., \& Milošević, B. (2009). Genetic resources of field pea in Serbia. Pisum Genetics, 41: 44-45.

Mihailović, V., Mikić, A., Katić, S., Karagić, Đ., \& Milošević, B. (2010). Potencijal stočnog graška za prinos proteina krme i zrna. Ratar. Porrt. 47: 43-48. 
Mikić, A., Mihailović, V., Hauptvogel, P., Ćupina, B., Petrović, M., Krstić, Đ., Jovičić, D., Milošević, B., \& Hauptvogel, R. (2009). Wild populations of vetches (Vicia) as forage and green manure crops for temperate regions. Irish Journal of Agricultural and Food Research, 48:265.

Milošević, M., Dragin, S., \& Stegić, M. (2009). Biljni genetički diverzitet u poljoprivredi, Poljoprivredni fakultet, Novi Sad.

Milošević, M., Dragin, S., \& Stegić, M. (2010). Značaj genetičkih resursa i način njihovog očuvanja, Ratar. Povrt. 47(1): 1-19.

Milošević, M., Miloradov, M., Dragin, S., \& Stegić, M. (2010). The importance of genetic resources in agriculture, Genetics 42(3).

Milošević, M., Dragin, S., Stegić, M., \& Mikić, A.(2010). Biotechnology and Biodiversity. 7th IMT-GT UNINET and the $3^{\text {rd }}$ Joint International PSU-UNS Conference BioScience in the future. pp. 1-11 Prince of Songkla University, http:// rdo.psu.ac.th/bioscience2010/.

Milošević, M., Mikić, A., Marjanović-Jeromela, A., \& Milošević, D. (2012). Organic agriculture and food production. XVI International Eco-Conference 26-29 September 2012, Safe Food, Novi Sad, Ecological Movement of Novi Sad, pp. 33-49.

NBSAP (2013). Biodiversity in Bosnia and Herzegovina, national Strategy for Biodiversity and Action Plan, http://www.bihchm-cbd.ba/Bos/bib_bos.htm.

Olson, D. M., Dinerstein, E., Wikramanayake, D., Burgess, N. D., Powell, G. V. N., Underwood, J. A., Itoua, I., Strand, H. E., Morrison, J.C., Loucks, O.L, Allnut, T.F., Ricketts, T.H., Kura, Y., Lamoreux, J.F., Wettengel, W. W., Hedao, P., \& Kassem, K.R. (2001). Terrestrial ecoregions of the world: a new map of life on Earth. Bioscience 51: 933-938. http:// www.sciencedaily.com/ releases $/ 2005 / 05 / 050512112311 . h t m$

Power, S. (2008). Field of the future, Imperial College Reporter, London, http://www3.imperialac.uk/pls/portallive/docs/1/49981703.PDF

Power, S., \& Pete-Manning, P. (2008). Field Of The Future, Ecological Experiment Simulates Conditions In 2100, ScienceDaily, http:// www.sciencedaily.com/releases/2008/09/080926100636.htm

Reid, W.V., Mooney, H. A., Cropper, A., Capistrano, D., Carpenter, S. R., Chopra, K., Dasgupta, P., Dietz, T. Duraiappah, A. K., Hassan, R., Kasperson, R., Leemans, R., May, R. M., McMichael, A. J., Pingali, P., Samper, C., Scholes, R., Watson, R. T., Zakri, A. H., Shidong, Z., Ash, N. J., Bennett, E., Kumar, P., Lee, M. J., Raudsepp - Hearne, C., Simons, H., Thonell, J., \& Zurek, M.B. (2005). Millennium ecosystem assessment synthesis report. Island Press, Washington, D.C., USA.

Sala, O.E., F.S. Chapin, III, J.J. Armesto, E. Berlow, J. Bloomfield, R. Dirzo, E. Huber-Sanwald, L.F. Huenneke, R. Jackson, A. Kinzig, R. Leemans, D. Lodge, H.A. Mooney, M. Oesterheld, L. Poff, M.T. Sykes, B.H. Walker, M. Walker, \& Wall, D. (2000). Global biodiversity scenarios for the year 2100. Science 287: 1770-1774.
Sala, O.E., D.P., van Vuuren, P., Pereira, D., Lodge, J., Alder, G., Cumming, A., Dobson, V., Wolters, M. A., Xenopoulos, A. S., Zaitsev, M. G., Polo, I., Gomes, C., Queiroz, J.A., \& Rusak. E. (2006). Biodiversity across scenarios. p. 375-408 In: S. Carpenter and P. Pingali, (eds). Ecosystems and human well -being: scenarios. Island Press, Washington, D.C., USA, www.ecologyandsociety.org/vol11/iss2/art25/ES-20061818.pdf

Savić, A., G. Petrović, M. Milošević, Z. Nikolić, A. Stojanović, J. Gvozdenović-Varga, V. Todorović \& M. Vasić (2014). Morpho-chemical characterization of dry and snap bean (Phaseolus vulgaris L.) landraces collected on Fruška Gora MT. Genetika 46(1): 301-313.

Science Daily (2007). New Study Finds Biodiversity Conservation Secures Ecosystem Services For People, Adapted from materials provided by Conservation International, via EurekAlert!, a service of A A A S. http: / / www.sciencedaily.com/ releases/2007/12/071205131149.htm

Töpfer, K. (2008). Protecting Biodiversity Is Critical to Mankind's Survival', The interview was conducted by Rafaela von Bredow and Sebastian Knauer www.spiegel.de/ international/world/0,1518,555091,00.html

Udruženje građana-Škola za opstanak (2004). Dan zaštite životne sredine, Ekološko društvo ENDEMIT.

United Nations Environment Programme (2007). TEEB - The Economics of Ecosystems and Biodiversity. http://www.unep.org/ greeneconomy/index 2 .asp?id=teeb

UNEP (2002). Global environment outlook.

Van Vuuren, D.P., Sala, O.E., \& Pereira, H.M. (2006). The Future of Vascular Plant Diversity Under Four Global Scenarios, Ecology and Society 11(2): 25. http:// www.ecologyandsociety.org/vol11/iss2/art25/Island

Van Vuuren, D.P., Osvaldo, E., Sala, O.E., \& Pereir, H.M. (2008) The Future of Vascular Plant Diversity Under Four Global Scenarios, Ecology and Society 11(2): 25, http:// www.ecologyandsociety.org/vol11/iss2/art25/

Venail, P.A., MacLean, R.C., Bouvier, T., Brockhurst, M.A., Hochberg, M.E.,\& Mouquet, N. (2008). When Evolution Tends To Maximize the Diversity And Functioning Of Ecosystem, material used: Functional Diversity and Productivity Peak at Intermediate Levels of Dispersal in Evolving Metacommunities, ScienceDaily. http:// www.sciencedaily.com-/Releases/2008/03/080330212514.htm;

Venail, P.A., MacLean, R.C., Bouvier, T. Brockhurst, M.A.,Hochberg, M.E., \& Mouquet, N. (2007). Diversity and productivity peak at intermediate dispersal rate in evolving metacommunities, Nature 452: 210-21.

Veselinović, J., Milošević, M., \& Počuča, S. (2014). Intenational treaty on plant genetic resources for food and agriculture as a basis for limiting intellectual property of plant breeders in Serbia. Economics of Agriculture 61(1): 211-223.

\section{Biodiverzitet i osnovni aspekti njegovog održanja}

\section{Mirjana Milošević · Aleksandar Mikić · Ana Marjanović Jeromela}

Sažetak: Biodiverzitet, ili raznolikost u biljnim resursima u poljoprivredi, je biološka osnova obezbeđenja sveta hranom, direktno ili indirektno. Biodiverzitet podrazumeva diverzitet genetičkog materijala sadržanog u tradicionalnim i u novostvorenim savremenim genotipovima. Pomenuti resursi mogu biti osnova za stvaranje novih sorti kroz proces konvencionalnog ukrštanja ili primenom biotehnologije. Biljni resursi podrazumevaju i divlje srodnike i druge divlje biljne vrste koje mogu da se koriste kao izvor energije, $u$ farmaceutske svrhe, kao izvor poželjnih gena. Bez obzira za koju svrhu i koja tehnologija se koristi genetički materijal je rezervoar genetičke adaptabilnosti koji može da se pokaže kao pufer protiv potencijalno štetnih spoljašnjih ili ekonomskih promena. Erozija biljnih resursa može da ima ozbiljan i dugoročan uticaj na snabdevanje hranom.

Ključne reči: biljni resursi, biodiverzitet, genetika, diverzitet, ekonomski razvoj, ekosistemi, klimatska promena, održanje 